\title{
Effect of Fertilization on the Dynamics and Activity of Iron-Reducing Bacterial Populations in a West African Rice Paddy Soil Planted with Two Rice Varieties: Case Study of Kou Valley in Burkina Faso
}

\author{
Cécile Harmonie Otoidobiga ${ }^{*}$, Adama Sawadogo', Yapi Sinaré2, Ibrahima Ouédraogo², \\ Prosper Zombré ${ }^{3}$, Susumu Asakawa4 ${ }^{4}$, Alfred S. Traore', Dayéri Dianou ${ }^{5}$ \\ ${ }^{1}$ Research Center for Biological, Alimentary and Nutritional Sciences, Research and Training Unit, Life and Earth \\ Sciences, University of Ouagadougou, Ouagadougou, Burkina Faso \\ ${ }^{2}$ Institute of Environment and Agricultural Research, Bobo Dioulasso, Burkina Faso \\ ${ }^{3}$ Laboratory of Soil-Materials and Environment, Research and Training Unit, Life and Earth Sciences, University \\ of Ouagadougou, Ouagadougou, Burkina Faso \\ ${ }^{4}$ Soil Biology and Chemistry, Graduate School of Bio-Agricultural Sciences, Nagoya University, Chikusa, Nagoya, \\ Japan \\ ${ }^{5}$ National Center for Sciences and Technology Research, Ouagadougou, Burkina Faso \\ Email: “Cecile.otoidobiga@univ-ouaga.bf
}

Received 7 June 2016; accepted 22 July 2016; published 26 July 2016

Copyright (C) 2016 by authors and Scientific Research Publishing Inc.

This work is licensed under the Creative Commons Attribution International License (CC BY).

http://creativecommons.org/licenses/by/4.0/

(c) (7) Open Access

\section{Abstract}

Iron toxicity is a major stress to rice caused by a high concentration of reduced iron, in the soil in many lowlands worldwide. To reduce iron toxicity in the West African lowlands, an investigation was performed at the site of the University of Ouagadougou, in pots containing an iron toxic soil from the Kou Valley (West of Burkina Faso). The experiment objective was to study the effect of mineral fertilizer on Iron Reducing Bacteria (IRB) dynamics and activity during rice cultivation, iron accumulation in rice plant and rice biomass yield under iron toxicity conditions. BOUAKE-189 and ROK-5 rice varieties, sensitive and tolerant to iron toxicity, respectively, were used for the experiment. The pots were amended with chemical fertilizers (NPK + Urea and NPK + Urea + Ca + Mg + Zn complex). Control pots without fertilization were prepared similarly. The kinetics of IRB and ferrous iron content in soil near rice roots were monitored throughout the cultural cycle using MPN and colorimetric methods, respectively. The total iron content was evaluated in rice plant

${ }^{*}$ Corresponding author.

How to cite this paper: Otoidobiga, C.H., et al. (2016) Effect of Fertilization on the Dynamics and Activity of Iron-Reducing Bacterial Populations in a West African Rice Paddy Soil Planted with Two Rice Varieties: Case Study of Kou Valley in Burkina Faso. Journal of Environmental Protection, 7, 1119-1131. http://dx.doi.org/10.4236/jep.2016.78101 
using spectrometric method. Data obtained were analyzed in relation to fertilization mode, rice growth stage and rice yield using the student's t-test and XLSTAT 2014 statistical software. The experiment revealed that NPK + Urea and NPK + Urea + Ca + Mg + Zn fertilization, decreased significantly $(p<0.0001)$ the number of IRB in the soil for BOUAKE-189 rice varieties. In most pots, highest IRB densities and ferrous iron content in soil were recorded from rice tillering and flowering to maturity stages, indicating that rice plants promoted microbial processes and iron reduction in soil. From the study, the NPK + Urea amendment decreased significantly ferrous iron content $(p<0.0001)$ in soil near BOUAKE-189 and ROK-5 rice varieties roots relatively to control pots. However, NPK + Urea + Ca + Zn + Mg amendment increased significantly ferrous iron content $(p<0.0001)$ in the soil near roots, Fe accumulation in plant biomass and rice yield for the two rice varieties.

\section{Keywords}

Iron-Reducing Bacteria, Rice, Iron Toxicity, Fertilization

\section{Introduction}

Iron is the fourth-most abundant element in the Earth's crust and the most prevalent redox-active metal [1] [2]. Iron is a first row transition metal which mainly exists in one of the two readily inter-convertible redox states under physiological conditions: the reduced $\mathrm{Fe}^{2+}$ ferrous form and the oxidised $\mathrm{Fe}^{3+}$ ferric form. Iron can also adopt different spin states (high or low) in both the ferric and ferrous form, depending on its ligand [3] [4]. These properties permit to the iron to participate in many major biological processes, such as photosynthesis, $\mathrm{N}_{2}$ fixation, methanogenesis, production and consumption of $\mathrm{H}_{2}$, respiration, the trichloroacetic acid (TCA) cycle, oxygen transport, gene regulation and the biosynthesis of DNA [5]-[7]. Iron is absolutely required for all forms of life; however, a large concentration of reduced iron $\left(\mathrm{Fe}^{2+}\right)$ in the soil solution can cause high production of oxygen radicals which can damage cell structural components and impair physiological processes of plants [3] [8] [9].

Rice (Oryza sativa L.) is cultivated on approximately 213.7 million hectares of irrigated and rained lowlands in the world [10]-[12]. Since the first report of its occurrence [13], the iron toxicity for rice in lowland has been largely reported in several countries, especially in the humid tropical regions in Asia, South America and West and Central Africa [14]-[17]. By overlaying the soil map with the rice distribution map [12], it is roughly estimated that $19 \%$ of the total rice area in Africa has a potential risk of Fe toxicity. Chérif et al. [18] have reported that about $55 \%$ of the rice area is affected by iron toxicity in three West African countries (Guinea, Ivory Coast and Ghana), and about $10 \%$ of the area of rice cultivation is abandoned due to severe iron toxicity [19] [20]. In Burkina Faso, many lowland crop fields were even abandoned due to iron toxicity [21]. The Kou Valley is recognized as an excellent agricultural plain, because of its great hydraulic potential and the soils fertility [22]. With an area of 1200 hectares, the Kou valley belongs to the first irrigated perimeters (1960) of Burkina Faso [22]. However, in 1986, 300 ha of fields were abandoned, in Kou Valley because of ferrous intoxication [21]; and most among these intoxicated fields remained uncultivated up to date [23].

Iron toxicity is one of the most important edaphic constraints to rice production on acid soils [9] [24]. The iron toxicity conditions are most frequently reported from inland valley, swamps and coastal or tidal wetlands [25]. Many studies show that the occurrence of Fe toxicity is associated with a high concentration of Fe (II) in soil solution [11] [15] [26]. Thus, large concentrations of ferrous Fe in soil solution may occur either when Fe is mobilized in situ by microbial reduction of ferric iron [27] or when reduced $\mathrm{Fe}$ is translocated into valley bottoms by interflow or subsurface flow from adjacent slopes [19] [28] [29].

The microbial reduction of iron is considered to be an ubiquitous and important redox process, in which IRB can gain energy for growth by coupling the oxidation of organic compounds or hydrogen with the reduction of $\mathrm{Fe}$ (III) [30]-[33]. The soils of rice fields are intermediate between upland systems and the true aquatic systems, and the alternation between anoxic and oxic conditions causes periodically the occurrence of redox reactions [32]. The IRB populations are abundant in paddy soils, because of the unique characteristics of these soils to 
provide abundant electron acceptors and substrates for their growth [32].

After the soil flooding by stagnant water, reductive processes start immediately; the dissolved oxygen is consumed by aerobic bacteria and chemical oxidation reactions [34]-[36]. Oxygen is depleted fast in most regions of the soil and alternative electron acceptors are used [37]. Therefore, within a few days, aerobic and facultative anaerobic microorganisms use the free oxygen and reduce the oxidized compounds of the soil such as nitrates, Mn (IV)-oxides, oxides of Fe (III) as well as sulfates [35] [38] [39]. In anoxic conditions, the Fe (III)-compounds are reduced and it results in ferrous ions production.

The appearance of iron toxicity symptoms in rice involves an excessive uptake of $\mathrm{Fe}^{2+}$ and $\mathrm{H}_{2} \mathrm{~S}^{-}$by the rice roots and its acropetal translocation into the leaves. The typical visual symptom associated with these processes is the "bronzing" of the rice leaves and substantial yield losses [11] [17] [18].

Many studies showed that Iron-induced yield is frequently associated with a poor nutrient status of the soil [40]. Indeed, the iron toxicity was described as a multiple nutritional disorder hastened by, but also increased by the deficiency of mineral $(\mathrm{P}, \mathrm{K}$, and $\mathrm{Zn})$ and $\mathrm{H}_{2} \mathrm{~S}^{-}$toxicity [25].

In order to determine the effect of chemical fertilization on microbiological and chemical parameters sustaining iron toxicity in paddy fields and on rice yield, the present study was conducted. Plastics pots were filled with a sensitive soil from Kou valley and amended by chemicals fertilizers. The iron-reducing bacterial populations' density, $\mathrm{Fe}^{2+}$ content in the paddy soil and iron accumulation in rice plant, were recorded during the cultural cycle of BOUAKE-189 and ROK-5 rice varieties (sensitive and tolerant to iron toxicity, respectively).

\section{Material and Methods}

\subsection{Sampling Site}

The soil used for the experiments was collected at Kou Valley, a site located at the West of Burkina Faso $\left(11^{\circ} 23^{\prime} 12^{\prime \prime} \mathrm{N}\right.$ and $\left.4^{\circ} 23^{\prime} 25^{\prime \prime} \mathrm{W}\right)$ and carried out to the experimental site of the University of Ouagadougou. The experiments were performed from June to November 2014. The physical and chemical proprieties of the soil studied are presented in Table 1 . The soil studied had a sandy-silt texture, a high iron content and a low organic matter.

\subsection{Pots Experiments}

Seventy two plastics pots with $25 \mathrm{~cm}^{3}$ of bulk were used in 3 replications throughout the study. At the bottom of each pot, an external tap was installed to sub-drain the soil. After 2 weeks of flooding, 15 day-old rice plants were transplanted. Two rice varieties, BOUAKE-189 [41] and ROK-5 [42], sensitive and resistant to iron toxicity, respectively were used. The soil was continuously flooded until rice maturity and harvest (120 days after flooding). Three replications and three modes of fertilization were performed throughout the study: without fertilization (control), NPK + Urea and NPK + Urea $+\mathrm{Zn}+\mathrm{Ca}+\mathrm{Mg}$, respectively. The doses of N-P-K (14-23-14), Urea, $\mathrm{CaCO}_{3}, \mathrm{ZnO}$ and $\mathrm{MgCl}_{2}$ application in pots were in the ratio of 720:240:50:22.4:20 $\mathrm{mg} / \mathrm{Kg}$ of dry soil according to the recommended doses of $300 \mathrm{~kg} / \mathrm{ha}$ for N-P-K, $100 \mathrm{~kg} / \mathrm{ha}$ for urea, $10 \mathrm{~kg} / \mathrm{ha}$ for ZnO, 250 $\mathrm{kg} / \mathrm{ha}$ for $\mathrm{CaCO}_{3}$ and $8.92 \mathrm{Kg} / \mathrm{ha}$ of $\mathrm{MgCl}_{2}$ [40] [41] [43]-[46].

\subsection{Enumeration of Iron-Reducing Bacterial Populations}

The numbers of Iron-Reducing Bacteria (IRB) were determined by the most-probable-number (MPN) method, using the basal medium adapted from Hammann and Ottow [35] as described by Otoidobiga et al. [36]. The enumeration of bacteria was performed before flooding when the soil was dried, on transplanting day (two weeks after flooding) and during the rice growth stages until harvest near rice hills.

Table 1. Physico-chemical characteristics of the Kou Valley soil.

\begin{tabular}{ccccccccccc}
\hline Depth $(\mathrm{cm})$ & $\begin{array}{c}\text { Clay } \\
(\%)\end{array}$ & $\begin{array}{c}\text { Silt } \\
(\%)\end{array}$ & Sand (\%) & MO (\%) & Total C (\%) & Total N (\%) & C/N & $\begin{array}{c}\mathrm{Fe}_{\mathrm{t}} \\
\mathrm{ppm}\end{array}$ & $\begin{array}{c}\mathrm{Fe}_{\mathrm{o}} \\
\mathrm{ppm}\end{array}$ & $\mathrm{pH}_{\mathrm{H} 2 \mathrm{O}}$ \\
\hline $0-10$ & 23.53 & 33.33 & 43.14 & 1.829 & 1.061 & 0.089 & 12 & 29.23 & 0.08 & $3.73-4.52$ \\
$10-20$ & 27.45 & 33.33 & 39.22 & 1.484 & 0.861 & 0.077 & 11 & 41.98 & 0.53 & $3.71-4.43$ \\
$20-40$ & 45.10 & 23.53 & 31.37 & 0.688 & 0.399 & 0.035 & 11 & 56.65 & 0.84 & $3.75-4.52$ \\
\hline
\end{tabular}

MO, Organic matter; C, Carbon; N, Nitrogen; C/N, Carbon to Nitrogen ratio; Fet, total amount of Fe; $\mathrm{Fe}_{\mathrm{o}}$, active Fe. 


\subsection{Determination of Ferrous Iron in Soil}

From the soil sampled for bacterial enumeration and at the same periods during the rice cultural cycle, the method of Vizier and Blanch [47] was used to measure the content of ferrous iron in the soil solution, using $0.2 \%$ ortho-phenantroline and $10 \%$ acetic acid reagents.

\subsection{Plant analysis}

The Total Fe was analysed in the leaves and roots of the two rice varieties. Young leaves were taken from each pot during the cultural cycle of rice. At harvest, the aerial biomass and the roots of each plant were also collected. The dried leaves and roots were digested with a mixture of concentrated $\mathrm{HNO}_{3}$ and $\mathrm{HClO}_{4}[48]$ and the total Fe content was determined by Atomic Absorption Spectrometry [49].

\subsection{Statistical Analysis}

Data obtained were analysed with regard to the IRB populations' development and activity, fertilization mode, rice growth stage and rice yield variations using the Student's t-test and XLSTAT 2014 statistical software. Mean parameters were compared according to the Fishers' test at 5\% probability level.

\section{Results and Discussion}

\subsection{Effect of Fertilization on IRB Populations Dynamics in Soil near BOUAKE-189 and ROK-5 Rice Roots}

The variance of the numbers of IRB in soil near rice roots, in relation to fertilization mode and rice growth stage is presented in Table 2. The Fishers' test revealed that the variance of the number of bacteria in the soil near BOUAKE-189 roots (sensitive to iron toxicity) was significantly related to fertilization ( $p<0.0001$ ), stage of rice growth $(p<0.0001)$ and combined both factors $(p=0.001$, Table 2$)$. Throughout the study, the average number of IRB population in the soil decreased significantly in NPK + Urea $+\mathrm{Ca}+\mathrm{Zn}+\mathrm{Mg}$ amended pots $(\mathrm{p}<$ 0.0001), relatively to the control (T) and NPK + Urea pots ones (Table 3).

It appeared also that no significant difference was observed for fertilization on IRB populations $(p=0.24)$ in the soil near rice roots of the tolerant rice variety (ROK-5) (Table 2). However, the mean density of IRB population in the soil decreased for $\mathrm{NPK}+$ Urea $+\mathrm{Ca}+\mathrm{Zn}+\mathrm{Mg}$ amended pots, relatively to the control (T) and

Table 2. Variance of IRB number in soil near rice roots in relation to fertilization and plant growth stage, during the cultural cycle of BOUAKE-189 and ROK-5 rice varieties.

\begin{tabular}{cccccccc}
\hline & \multicolumn{5}{c}{$\log$ (IRB number/g dry soil) } \\
\hline Source of variation & df & \multicolumn{2}{c}{ BOUAKE-189 } & \multicolumn{3}{c}{ ROK-5 } \\
\hline & & $\mathrm{F}$ & $\mathrm{p}$ & $\mathrm{F}$ & $\mathrm{p}$ \\
\hline Fertilization & 2 & 10.190 & $<0.0001^{*}$ & 1.432 & $0.240^{\text {ns }}$ \\
Stage of plant growth & 11 & 293.465 & $<0.0001^{*}$ & 303.055 & $<0.0001^{* *}$ \\
Fertilization* Stage of growth & 22 & 2.296 & $0.001^{* *}$ & 3.568 & $<0.0001^{* *}$ \\
\hline
\end{tabular}

$\mathrm{df}=$ degree of freedom; $\mathrm{F}=$ Fishers' $\mathrm{F} ;{ }^{*}$ significant $\mathrm{p}<0.05 ; * *$ significant $\mathrm{p}<0.01 ;{ }^{\text {ns }}$ not significant $\mathrm{p}<0.05$.

Table 3. Effect of fertilization on IRB population number in soil near rice roots during the cultural cycle of BOUAKE-189 and ROK-5 rice varieties in pots not fertilized $(\mathrm{T})$, and in pots fertilized with NPK + Urea and NPK $+\mathrm{Urea}+\mathrm{Ca}+\mathrm{Zn}+\mathrm{Mg}$ (means of 3 replicates).

\begin{tabular}{ccc}
\hline Fertilization & \multicolumn{1}{c}{$\log ($ IRB number/g dry soil) } \\
\hline NPK + Urea & BOUAKE-189 -5 & $8.110^{\mathrm{a}}$ \\
No Fertilization & $8.210^{\mathrm{a}}$ & $8.045^{\mathrm{a}}$ \\
$\mathrm{NPK}+$ Urea $+\mathrm{Ca}+\mathrm{Zn}+\mathrm{Mg}$ & $8.136^{\mathrm{a}}$ & $7.873^{\mathrm{a}}$ \\
\hline
\end{tabular}

Means with a same letter within a column are not significantly different according to Fishers' test $\mathrm{p}<0.05$. 


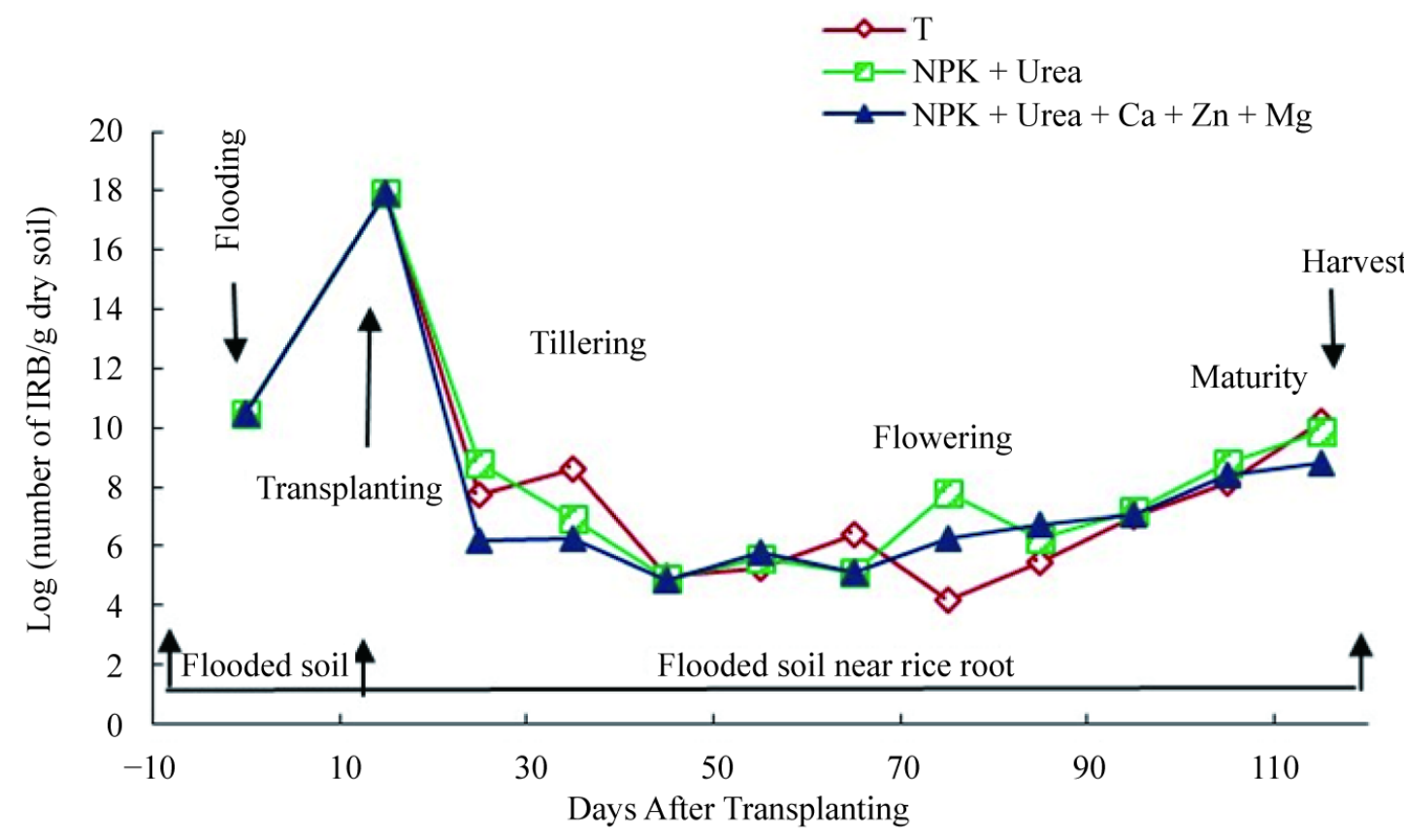

Figure 1. Densities of Iron-Reducing Bacteria in soil before flooding, at transplanting day, and in soil near rice roots during the cultural cycle of BOUAKE-189 rice variety in pots without fertilization (T), and in NPK + Urea and NPK + Urea $+\mathrm{Ca}+\mathrm{Zn}+\mathrm{Mg}$ fertilized pots, respectively (means of 3 replicates).

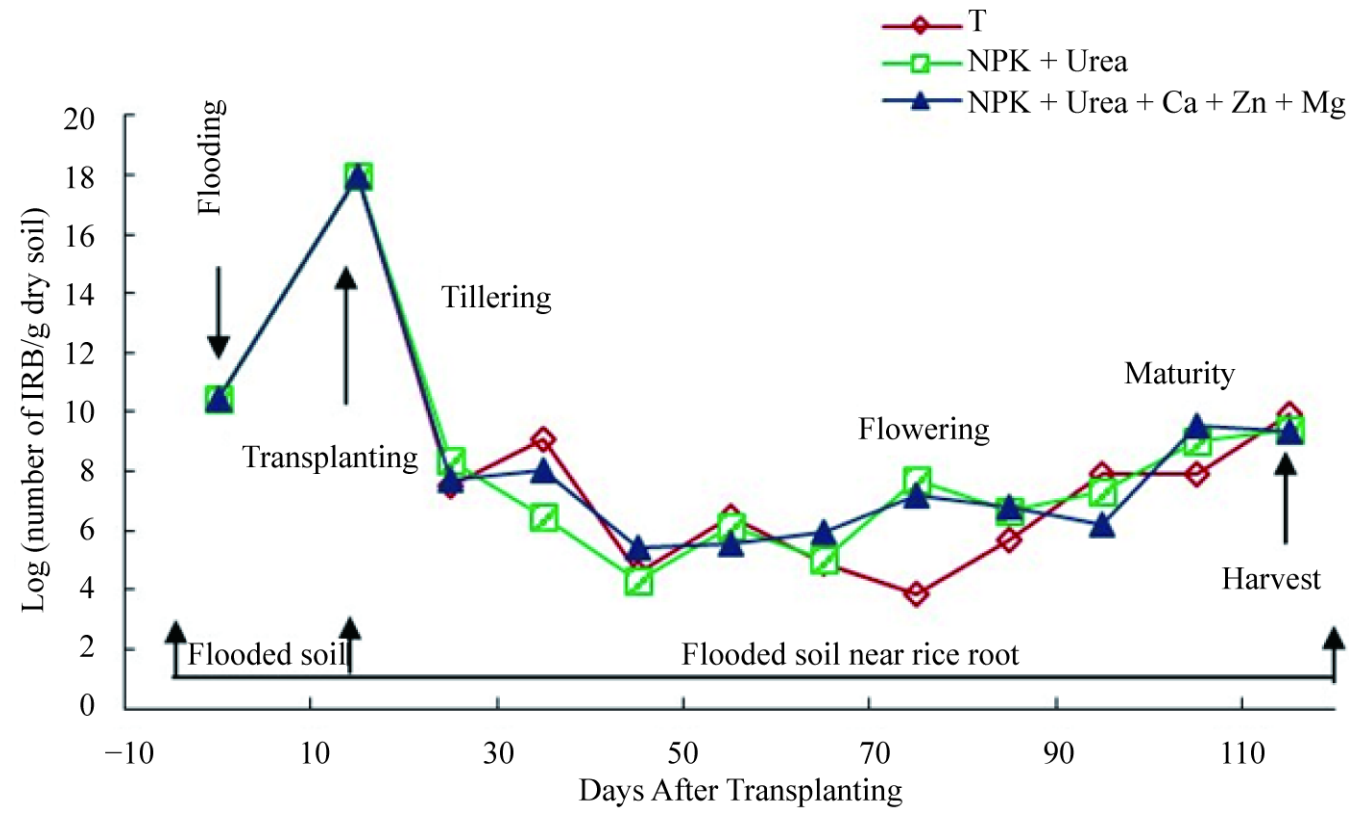

Figure 2. Densities of Iron-Reducing Bacteria in soil before flooding, at transplanting day, and in soil near rice roots during the cultural cycle of ROK-5 rice variety in pots without fertilization (T), and in NPK + Urea and $\mathrm{NPK}+\mathrm{Urea}+\mathrm{Ca}+\mathrm{Zn}+\mathrm{Mg}$ fertilized pots, respectively (means of 3 replicates).

NPK + Urea pots ones (Table 3). Study reported also that the number of IRB in the soil near rice roots was significantly related to the growth stage and combined effects of fertilization and growth stage $(p<0.0001)$ of ROK-5.

These results are in agreement with those found by Benckiser et al. [40] which showed that the number of iron-reducing bacteria decreased with increased supply of $\mathrm{K}, \mathrm{Ca}$, and $\mathrm{Mg}$ for IR22 and IR42 rice varieties (sus- 
ceptible and tolerant to iron toxicity, respectively). Thus, Trolldenier [50] found that a sufficient mineral nutrition of potassium, was important in maintaining the oxidising power of rice roots and in the reducing of IRB populations in rice fields.

The experiment showed also that the number of IRB in the soil near rice roots increased after two weeks of flooding in all pots for BOUAKE-189 and ROK-5 rice varieties (Figure 1, Figure 2). As reported by Hammann and Ottow [35], soon as a soil is flooded, oxygen is consumed by soil respiration (bacteria and fungi mainly) and a large amounts of mineral elements as Fe III and nutriments were released in the soil solution [51]. In these conditions, Fe III was used as electron acceptor by IRB for anaerobic respiration, coupled to the biodegradation of organic compounds [33] [37].

Figure 1 and Figure 2, showed that the number of IRB in soil near rice roots increased gradually with fluctuations from transplanting day to rice flowering and maturity stages in all the paddy pots. In most pots, the highest densities of IRB were recorded from rice tillering and flowering to maturity stages $\left(10^{8}\right.$ to $10^{18}$ cells/g dry soil). These results indicate that the presence of rice plants in the soils, influence and promote microbial processes, especially iron reduction [36] [52] [53].

These results are in agreement with those of Berthelin et al. [52] who also recorded a same evolution of IRB population during rice cultural cycle in a Senegal paddy soil. Our previous results [36] obtained on Kamboinse paddy soil, reported the same pattern. Indeed, as reported by many studies, tillering, flowering and maturity stages which correspond to the highest level of reduced soil condition may enhance the exudation of carbohydrates and other metabolites sustaining IRB population growth in soil [33] [36] [52].

\subsection{Effect of Mineral Fertilization on IRB Populations' Activity in Soil near the Roots of BOUAKE-189 and ROK-5 Rice Plants}

The variance of ferrous iron content in soil near rice roots in relation to fertilization and rice growth stage for both varieties is presented in Table 4. The Fishers' test revealed that ferrous iron content in soil near rice roots was significantly related to fertilization $(\mathrm{p}=0.009$ and $\mathrm{p}=0.049$, for BOUAKE-189 and ROK-5 rice varieties, respectively), rice growth stage $(\mathrm{p}<0.0001)$ and combined both factors $(\mathrm{p}<0.0001$, Table 4$)$, for iron sensitive (BOUAKE-189) and tolerant (ROK-5) rice varieties, respectively. The study, also revealed that ferrous iron content in soil decreased significantly $(\mathrm{p}=0.009$ and $\mathrm{p}=0.049$, for BOUAKE-189 and ROK-5 rice varieties, respectively) in the NPK + Urea amended pots relatively to the control pots (Table 5). Trolldenier [50] showed that the nutritional status of rice plant essentially influences bacterial activity and oxidation-reduction conditions around the roots. Thus, Trolldenier [50] and Prade et al. [53] found that potassium and phosphorus nutrition, separately or in combination, reduced ferrous iron content in soil by maintaining the oxidising power of rice roots and decreased the uptake of Fe (II), which seemed to be governed by soil $\mathrm{pH}$ or redox potential, respectively.

The experiment reported also that the average of the ferrous iron content in the soil near rice roots increased significantly $(p=0.009$ and $p=0.049)$ for the two rice varieties in the pots amended with NPK + Urea + Ca + $\mathrm{Zn}+\mathrm{Mg}$ (Table 5), relatively to the control pots. Many studies reported that the role of $\mathrm{Ca}, \mathrm{Mg}$, and $\mathrm{Zn}$ fertilizers is the regulation of ferrous iron absorption in the rice plant, both as competing ion and by increasing the plant tolerance to iron toxicity [11] [17]. Therefore, NPK + Urea $+\mathrm{Ca}+\mathrm{Zn}+\mathrm{Mg}$ application doesn't reduce ferrous iron production in rice fields but permit to rice plant to resist to the high content of toxic iron in soil.

In all pots, two peaks of intensive formation of Fe (II) occurred, one during two weeks after transplanting (primary iron toxicity) and the second between heading and flowering (Figure 3, Figure 4). In fact, in most pots, the highest content of ferrous iron in soil near rice roots was recorded from rice tillering and flowering to maturity stages at which it could reach $2.10^{3}$ to $6.10^{3} \mu \mathrm{g} / \mathrm{g}$ dry soil. These results can be explained by an increased root permeability ( $\mathrm{K}$ deficiency) and enhanced iron microbial reduction in the rizosphere due to intensive exudation during the physiological active phase between heading and flowering [33] [36] [53]. Thus, an improved energy supply (root debris and/or exudation of carbohydrates) stimulate microbial activity in general and anaerobic respiration (denitrification and/or ferric iron reduction) in particular [53].

\subsection{Impact of Fertilization on BOUAKE-189 and ROK-5 Rice Plants Total Iron Content}

The effect of fertilization on iron content in the BOUAKE-189 and ROK-5 rice varieties was measured during the study. Experiment showed that the total iron accumulation in BOUAKE-189 and ROK-5 rice plant was 
Table 4. Variance of ferrous iron content in soil near rice roots in relation to fertilization and rice growth stage during the cultural cycle of BOUAKE-189 and ROK-5 rice varieties in pots not fertilized (T), and in NPK + Urea and NPK + Urea + $\mathrm{Ca}+\mathrm{Zn}+\mathrm{Mg}$ fertilized pots.

\begin{tabular}{cccccccc}
\hline & & \multicolumn{5}{c}{ Ferrous iron content $(\boldsymbol{\mu g} / \mathbf{g}$ dry soil) } \\
\hline Source of variation & df & \multicolumn{2}{c}{ BOUAKE-189 } & \multicolumn{2}{c}{ ROK-5 } \\
\hline Fertilization & & F & p & F & p \\
Stage of growth & 2 & 4.731 & $0.009^{*}$ & 3.040 & $0.049^{*}$ \\
Fertilization* Stage of growth & 12 & 60.562 & $<0.0001^{* *}$ & 41.174 & $<0.0001^{* *}$ \\
\hline
\end{tabular}

$\mathrm{df}=$ degree of freedom; $\mathrm{F}=$ Fishers' $\mathrm{F} ; *$ significant $\mathrm{p}<0.05 ; * *$ significant $\mathrm{p}<0.01$.

Table 5. Mean concentration of ferrous iron in soil near rice roots during the cultural cycle of BOUAKE-189 and ROK-5, rice varieties, in pots not fertilized (T), NPK + Urea and NPK + Urea $+\mathrm{Ca}+\mathrm{Zn}+\mathrm{Mg}$ fertilized pots (means of 3 replicates).

\begin{tabular}{|ccc|}
\hline Fertilization & \multicolumn{2}{c|}{ Ferrous iron content $(\boldsymbol{\mu g} / \mathbf{g}$ dry soil) } \\
\hline & BOUAKE-189 & ROK-5 \\
\hline NPK + Urea $+\mathrm{Ca}+\mathrm{Zn}+\mathrm{Mg}$ & $0.0015^{\mathrm{a}}$ & $0.0016^{\mathrm{a}}$ \\
No fertilized & $0.00149^{\mathrm{a}}$ & $0.00143^{\mathrm{b}}$ \\
NPK + Urea & $0.0013^{\mathrm{b}}$ & $0.00142^{\mathrm{b}}$ \\
\hline
\end{tabular}

Means with a same letter within a column are not significantly different according to Fishers' test $\mathrm{p}<0.05$.

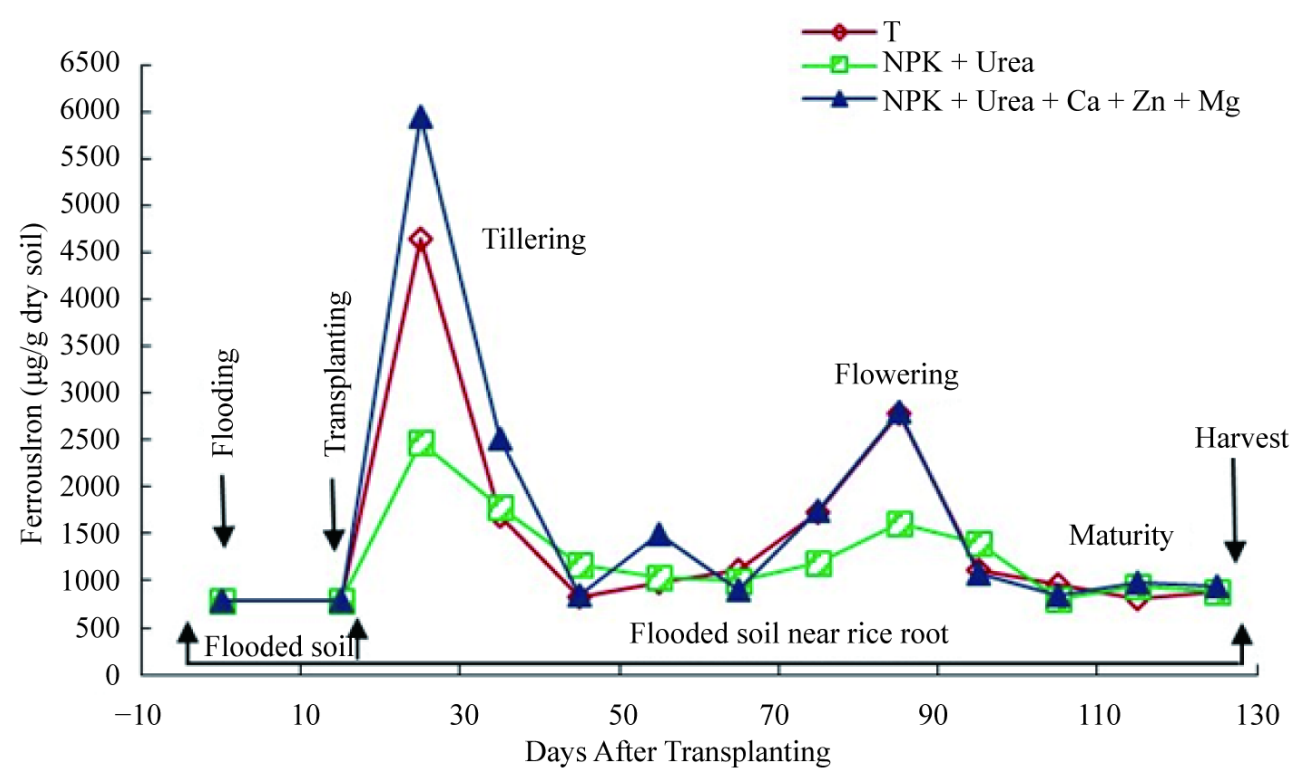

Figure 3. Evolution of the soil Ferrous iron content during the cultural cycle of BOUAKE-189 rice in pots not fertilized $(\mathrm{T})$, fertilized with NPK + Urea and NPK + Urea $+\mathrm{Ca}+\mathrm{Zn}+\mathrm{Mg}$, respectively (means of 3 replicates).

significantly related to fertilization $(\mathrm{p}<0.0001)$. From the results obtained the content of iron in the leaves increased from rice tillering to flowering and maturity stages (1.299 to $5.899 \mathrm{mg} / \mathrm{g}$ dry leaf, Table 6) during the cultural cycle of the two rice varieties. Iron mobilization in leaves increased critically according to Jones et al. [54], who reported that iron content in rice leaves become toxic when the content exceed $300 \mathrm{ppm}(\mathrm{Fe}>0.3$ $\mathrm{mg} / \mathrm{g}$ dry leaf). The values recorded from our study, were largely over this critical value. However, only the control pots of BOUAKE-189 rice variety showed symptoms, according to the IRRI standard evaluation systems for rice [37]. One reason of this result could be due to the susceptibility and tolerance of BOUAKE-189 and ROK-5 varieties to iron toxicity, respectively as reported [41] [42]. Some studies also reported that yield losses 


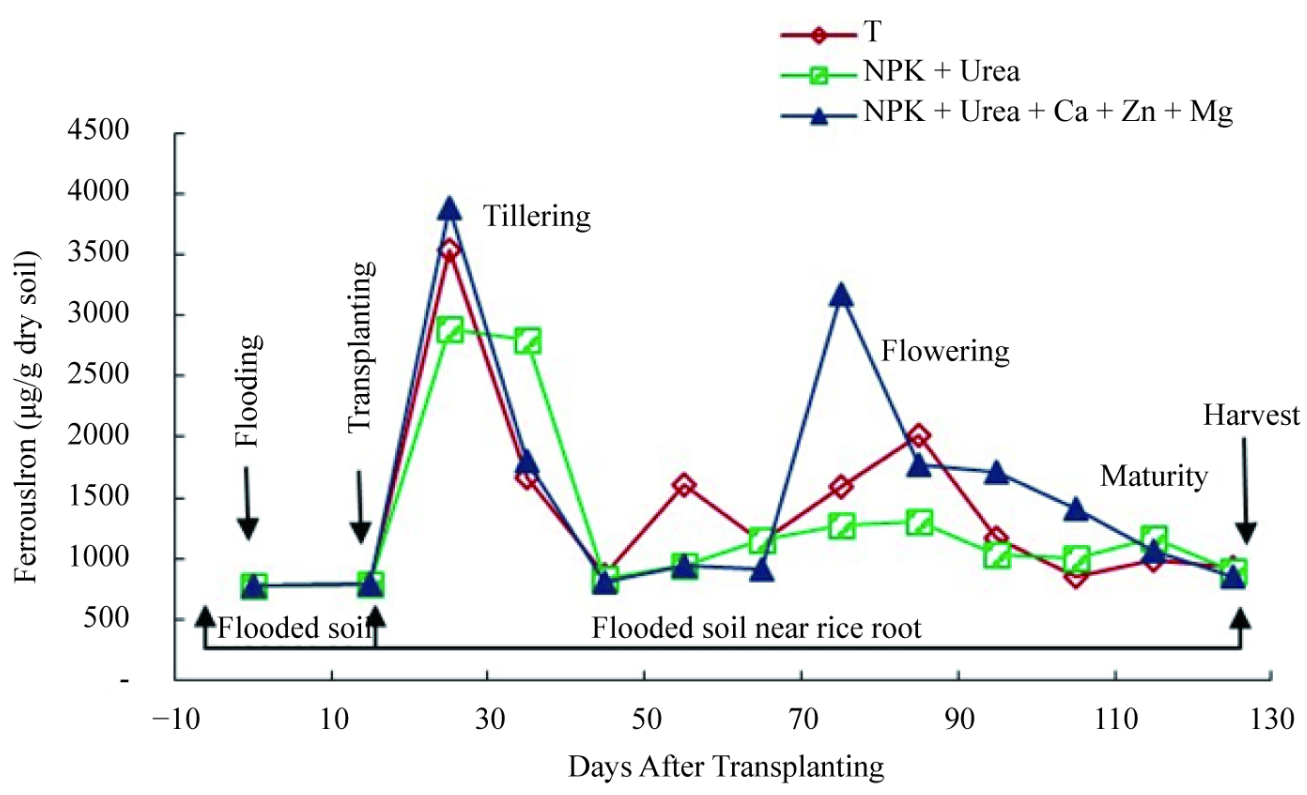

Figure 4. Evolution of the soil $\mathrm{Fe}^{2+}$ content during the cultural cycle of ROK-5 rice in pots not fertilized (T), fertilized with NPK + Urea and NPK + Urea $+\mathrm{Ca}+\mathrm{Zn}+\mathrm{Mg}$, respectively (means of 3 replicates).

Table 6. Effect of fertilization on iron content in the parts of BOUAKE-189 and ROK-5 rice plants in pots not fertilized (T), fertilized with NPK + Urea and NPK + Urea $+\mathrm{Ca}+\mathrm{Zn}+\mathrm{Mg}$ (means of 3 replicates).

\begin{tabular}{|c|c|c|c|c|c|c|c|c|c|c|}
\hline \multirow[b]{2}{*}{$\begin{array}{c}\text { Treatments }(\mathrm{mg} / \mathrm{g} \text { of dry } \\
\text { leaf) }\end{array}$} & \multicolumn{2}{|c|}{ Leaf-30d } & \multicolumn{2}{|c|}{ Leaf-60d } & \multicolumn{2}{|c|}{ Leaf-90d } & \multicolumn{2}{|c|}{ Biomass Aerial-120d } & \multicolumn{2}{|c|}{ Root-120d } \\
\hline & BOUAKE-189 & ROK-5 & BOUAKE-189 & ROK-5 & BOUAKE-189 & ROK-5 & BOUAKE-189 & ROK-5 & BOUAKE-189 & ROK-5 \\
\hline NPK + Urea & $2.188^{\mathrm{a}}$ & $3.188^{\mathrm{a}}$ & $2.266^{\mathrm{a}}$ & $3.266^{\mathrm{a}}$ & $1.854^{\mathrm{c}}$ & $2.854^{\mathrm{c}}$ & $3.248^{\mathrm{ab}}$ & $4.248^{\mathrm{ab}}$ & $4.899^{\mathrm{a}}$ & $5.899^{\mathrm{a}}$ \\
\hline $\begin{array}{l}\mathrm{NPK}+\text { Urea }+ \\
\mathrm{Ca}+\mathrm{Zn}+\mathrm{Mg}\end{array}$ & $1.846^{\mathrm{b}}$ & $2.846^{\mathrm{b}}$ & $2.163^{\mathrm{b}}$ & $3.163^{\mathrm{b}}$ & $2.215^{\mathrm{b}}$ & $3.215^{\mathrm{b}}$ & $3.865^{\mathrm{a}}$ & $4.865^{\mathrm{a}}$ & $2.495^{\mathrm{b}}$ & $3.495^{\mathrm{b}}$ \\
\hline No Fertilized & $1.911^{\mathrm{b}}$ & $2.911^{\mathrm{b}}$ & $1.299^{\mathrm{c}}$ & $2.299^{\mathrm{c}}$ & $2.611^{\mathrm{a}}$ & $3.611^{\mathrm{a}}$ & $2.345^{\mathrm{b}}$ & $3.345^{\mathrm{b}}$ & $2.947^{\mathrm{b}}$ & $3.947^{\mathrm{b}}$ \\
\hline
\end{tabular}

Means with a same letter within a column are not significantly different according to Fishers' test $\mathrm{p}<0.05$.

and the symptoms of leaf bronzing due to iron toxicity, were more pronounced in the dry-season as compared to the wet-season [28] [55]. Thus, in the present study, the period of experiment (wet season) may have reduced the appearance of the symptoms of iron toxicity.

The study revealed also that NPK $+\mathrm{Urea}+\mathrm{Ca}+\mathrm{Zn}+\mathrm{Mg}$ amended pots, had the greatest Fe content in aerial biomass at harvest, followed by NPK + Urea and control pots (no fertilization), respectively, for both varieties.

These results are in agreement with those of Panda et al. [56] who showed that the leaf iron content increased with the increases of N, P, and K application for Sharbati, IR-64 and Lalat rice varieties. Panda et al. [56] found also that among the nutrients, $\mathrm{N}$ was most effective in increasing leaf Fe concentration, followed by $\mathrm{P}$ and $\mathrm{K}$ for the three rice cultivars tested.

Panda et al. [56] explained the physiological and biochemical mechanisms that improve Fe uptake under a favourable N, P or K nutrition. Therefore, rice plants release the siderophores into the rhizosphere, which bind to $\mathrm{Fe}^{3+}$ in the form of a ligand. The ligand complex enters into the cell, and $\mathrm{Fe}^{3+}$ is reduced into $\mathrm{Fe}^{2+}$ inside the cytoplasm. Thus, NPK applications might contributed to Fe acquisition by enabling the plant to synthesize more photosynthetic assimilates and more reducing power $(\mathrm{NADPH}+\mathrm{H}+)$, which might helped in the synthesis and release of more siderophores in the rice rhizosphere and subsequent reduction of $\mathrm{Fe}^{3+}$ to a soluble ferrous form. Thus, the mineral amendment ( $\mathrm{Ca}, \mathrm{Mg}, \mathrm{Mn} \mathrm{P}, \mathrm{K}$ and $\mathrm{Zn}$ ) in iron toxicity conditions seems to promote leaf tissue tolerance to excess amounts of $\mathrm{Fe}[57]$ and to optimize $\mathrm{Fe}^{3+}$ absorption in the rice plant for a better growth and better yield [17].

The NPK + Urea amended pots showed also the highest content of total Fe in roots at harvest followed by $\mathrm{NPK}+\mathrm{Urea}+\mathrm{Ca}+\mathrm{Zn}+\mathrm{Mg}$ and the control pots, respectively, for the two rice varieties. Therefore, NPK + 
Urea and NPK + Urea $+\mathrm{Ca}+\mathrm{Zn}+\mathrm{Mg}$ applications seem to promote also the capacity of BOUAKE-189 and ROK-5 rice varieties to survive into an iron toxicity condition by oxidizing $\mathrm{Fe}$ II into their $\mathrm{Fe}^{3+}$ forms at the root surface (Fe-excluding power) [58] [59].

The experiment reported also that the iron tolerant rice variety (ROK-5), showed the highest accumulation of iron than the sensitive rice variety (BOUAKE-189) and the content of iron in the roots was significantly higher than in the aerial biomass. These results can be explained by the physiological mechanisms of iron (II) avoidance and/or tolerance of rice plants in order to survive under Fe-toxic condition [60] [61]. Therefore, ROK-5 rice variety can survive to iron toxicity by oxidation of ferrous iron at the root surface (Fe-oxidizing power) [52], exclusion of $\mathrm{Fe}$ at the root surface (Fe-excluding power), retention of $\mathrm{Fe}$ in the root tissue (Fe-retaining power) [58] [59] or by leaf tissue tolerance to excess amounts of $\mathrm{Fe}$ [57].

\subsection{Impact of Fertilization on BOUAKE-189 and ROK-5 Rice Varieties Yield}

From our results, a significant difference $(\mathrm{p}<0.0001)$ was found for the rice biomass yield among treatments for both varieties (BOUAKE-189 and ROK-5). Our study reported also that ROK-5 rice variety (tolerant to iron toxicity) recorded the highest biomass yield among treatments. Thus, as reported by Mahato et al. [62], the yield parameters of the rice plant in iron toxicity conditions, is related to genetic variation of cultivars.

The pots which received NPK + Urea $+\mathrm{Ca}+\mathrm{Zn}+\mathrm{Mg}$ application, recorded also the highest yield followed by NPK + Urea and the control pots (Figure 5). These results are in agreement with those obtained by Panda et al. [56] which reported that plant biomass and grain yield of all cultivars were improved by the applications of Nitrogen, Potassium and Phosphorus. Also, depending on the soil and the season, application of $\mathrm{P}, \mathrm{K}, \mathrm{Ca}, \mathrm{Mg}$, and $\mathrm{Zn}$, solely or in combinations, can reduce bronzing symptoms and increase rice yield [3] [29] [41] [56]. Shu and Chung [63] reported also that it is possible that absorption of $\mathrm{N}, \mathrm{P}$, and $\mathrm{K}$ by the plant increases biomass and grain yield in rice because the nutrients play positive roles directly or indirectly on leaf photosynthesis to improve primary production. The application of essential plant nutrients can also counteract negative effects of excess amounts of iron, by competing with $\mathrm{Fe}^{2+}$ uptake at the sites of ion adsorption of the root or by enhancing plants' defence or tolerance mechanisms [25]. Fageria et al. [17] and Sahrawat [11] also revealed that Zinc application increased the tolerance of rice to an elevated content of reduced iron in the soil. Therefore, a chemical amendment (Ca, Mg, Mn P, K and $\mathrm{Zn}$ ) can play an important role in the regulation of Fe up-take in the rice plant by optimizing the $\mathrm{Fe}^{3+}$ absorption in the rice plant for a better growth and yield [17].

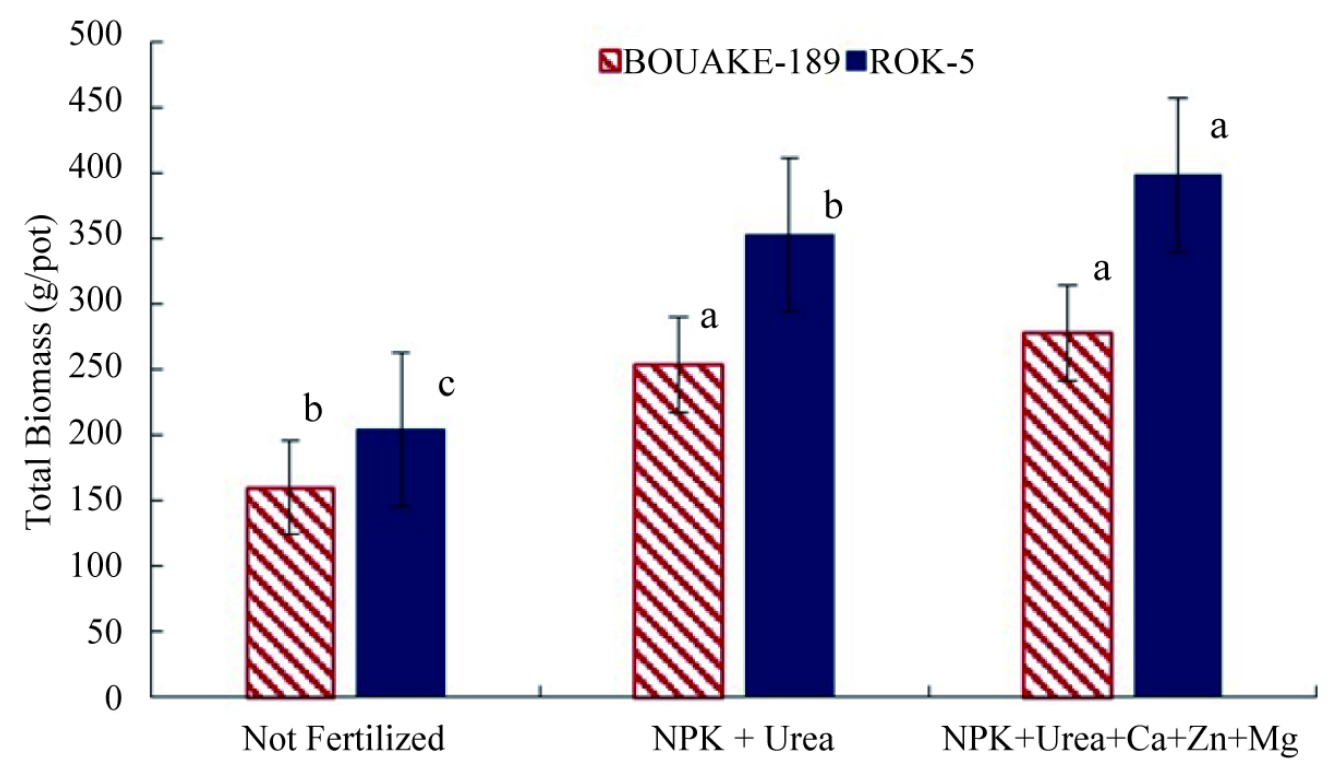

Fertilization Mode

Figure 5. Yield of total biomass of BOUAKE-189 and ROK-5 rice varieties in pots not fertilized, fertilized with NPK + Urea and NPK + Urea $+\mathrm{Ca}+\mathrm{Zn}+\mathrm{Mg}$, respectively (means of 3 replicates). Yields sharing the same letter are not significantly different according to Fishers' test $p<0.05$. 


\section{Conclusions}

The experiment revealed that mineral fertilization (NPK, Urea, Ca, Zn, Mg) decreased significantly the number of IRB in the soil near the roots of ROK-5 and BOUAKE-189 rice varieties (iron tolerant and iron susceptible rice varieties, respectively). However, in all pots, the highest densities of IRB and ferrous iron content in soil near rice roots were recorded from rice tillering and flowering to maturity stages. This result indicates that the presence of rice plants in the soils, influences and favours microbial processes and iron reduction by an intensive exudation during the physiological active phase between heading and flowering.

The study reported also that NPK + Urea amendment decreased significantly ferrous iron content in soil near rice roots relatively to control pots. However, amendment of rice fields with $\mathrm{NPK}+\mathrm{Urea}+\mathrm{Ca}+\mathrm{Zn}+\mathrm{Mg}$ fertilizers increased significantly the ferrous iron content in the soil near rice roots and accumulated the greatest Fe content for iron sensitive and tolerant rice varieties. In fact, Potassium and Phosphorus nutrition, separately or in combination, reduce ferrous iron content in soil by maintaining the oxidising power of rice roots and decrease $\mathrm{Fe}$ (II) uptake. However, NPK + Urea $+\mathrm{Ca}+\mathrm{Zn}+\mathrm{Mg}$ application didn't reduce ferrous iron production in rice fields but permitted a high resistance to rice plant to survive in condition of iron toxicity in soil. Application of $\mathrm{P}, \mathrm{K}, \mathrm{Ca}, \mathrm{Mg}$, and $\mathrm{Zn}$, solely or in combinations has been also reported to reduce bronzing symptoms and to increase rice yield depending on the soil and the season. The study showed also that the pots which received NPK + Urea $+\mathrm{Ca}+\mathrm{Zn}+\mathrm{Mg}$ application, recorded the highest yield followed by NPK + Urea and the control for the two rice varieties.

\section{Acknowledgements}

The authors would like to express profound gratitude to CNRST/IRSS, International Foundation for Science, CIOSPB, PACER-UEMOA/RABIOTECH, FCN/WAAPP and CNS-FL/WAAPP, for financial and technical supports.

\section{References}

[1] Hauck, S., Benz, M., Brune, A. and Schink, B. (2001) Ferrous Iron Oxidation by Denitrifying Bacteria in Profundal Sediments of a Deep Lake (Lake Constance). FEMS Microbiology Ecology, 37, 127-134. http://dx.doi.org/10.1111/j.1574-6941.2001.tb00860.x

[2] Yan, J.-M., Zhang, X.-B., Han, S., Shioyama, H. and Xu, Q. (2008) Iron-Nanoparticle-Catalyzed Hydrolytic Dehydrogenation of Ammonia Borane for Chemical Hydrogen Storage. Angewandte Chemie, 120, 2319-2321. http://dx.doi.org/10.1002/ange.200704943

[3] Sahrawat, K.L. (2003) Iron Toxicity in Wetland Rice: Occurrence and Management through Integration of Genetic Tolerance with Plant Nutrition. Journal of the Indian Society of Soil Science, 51, 409-417.

[4] Schärer, M., De Grave, E., Semalulu, O., Sinaj, S., Vandenberghe, R.E. and Frossard, E. (2009) Effect of Redox Conditions on Phosphate Exchangeability and Iron Forms in a Soil Amended with Ferrous Iron. European Journal of Soil Science, 60, 386-397. http://dx.doi.org/10.1111/j.1365-2389.2009.01135.x

[5] Andrews, S.C., Robinson, A.K. and Rodríguez-Quiñones, F. (2003) Bacterial Iron Homeostasis. FEMS Microbiology Reviews, 27, 215-237. http://dx.doi.org/10.1016/S0168-6445(03)00055-X

[6] De Souza, R., Meyer, J., Schoenfeld, R., Da Costa, P.B. and Passaglia, L.M.P. (2015) Characterization of Plant Growth-Promoting Bacteria Associated with Rice Cropped in Iron-Stressed Soils. Annals of Microbiology, 65, $951-964$. http://dx.doi.org/10.1007/s13213-014-0939-3

[7] Kobayashi, T. and Nishizawa, N.K. (2012) Iron Uptake, Translocation, and Regulation in Higher Plants. Annual Review of Plant Biology, 63, 131-152. http://dx.doi.org/10.1146/annurev-arplant-042811-105522

[8] Au-Yeung, H.Y., Chan, J. and Chantarojsiri, T.C.C. (2013) Molecular Imaging of Labile Iron(II) Pools in Living Cells with a Turn-On Fluorescent Probe. Journal of the American Chemical Society, 135, 15165-15173. http://dx.doi.org/10.1021/ja4072964

[9] Quinet, M., Vromman, D., Clippe, A., Bertin, P., Lequeux, H., Dufey, I., Lutts, S. and Lefèvre, I. (2012) Combined Transcriptomic and Physiological Approaches Reveal Strong Differences between Short- and Long-Term Response of Rice (Oryza sativa) to Iron Toxicity. Plant, Cell and Environment, 35, 1837-1859. http://dx.doi.org/10.1111/j.1365-3040.2012.02521.x

[10] Maclean, J.L., Dawe, D.C., Hardy, B. and Hettel, G.P. (2002) Rice Almanac. CABI Publishing, Wallingford, UK.

[11] Sahrawat, K.L. (2010) Reducing Iron Toxicity in Lowland Rice with Tolerant Genotypes and Plant Nutrition. Plant 
Stress, 4, 70-75.

[12] Haefele, S.M., Nelson, A. and Hijmans, R.J. (2014) Soil Quality and Constraints in Global Rice Production. Geoderma, 235-236, 250-259. http://dx.doi.org/10.1016/j.geoderma.2014.07.019

[13] Ponnamperuma, F.N., Bradfield, R. and Peech, M. (1955) Physiological Disease of Rice Attributable to Iron Toxicity. Nature, 175, 265-265. http://dx.doi.org/10.1038/175265a0

[14] Kyuma, K. (2004) Paddy Soil Science. http://www.cabdirect.org/abstracts/20053058031.html;jsessionid=21688EE7798DC994EB1EF0E9C29F0387

[15] Sahrawat, K.L. (2004) Iron Toxicity in Wetland Rice and the Role of Other Nutrients. Journal of Plant Nutrition, 27, 1471-1504. http://dx.doi.org/10.1081/PLN-200025869

[16] Balasubramanian, V., Sie, M., Hijmans, R.J. and Otsuka, K. (2007) Increasing Rice Production in Sub-Saharan Africa Challenges and Opportunities. Advances in Agronomy, 94, 55-133. http://dx.doi.org/10.1016/S0065-2113(06)94002-4

[17] Fageria, N.K., Santos, A.B., Barbosa Filho, M.P. and Guimarães, C.M. (2008) Iron Toxicity in Lowland Rice. Journal of Plant Nutrition, 31, 1676-1697. http://dx.doi.org/10.1080/01904160802244902

[18] Chérif, M., Audebert, A., Fofana, M. and Zouzou, M. (2009) Evaluation of Iron Toxicity on Lowland Irrigated Rice in West Africa. Tropicultura, 27, 88-92.

[19] Engel, K., Asch, F. and Becker, M. (2012) Classification of Rice Genotypes Based on Their Mechanisms of Adaptation to Iron Toxicity. Journal of Plant Nutrition and Soil Science, 175, 871-881. http://dx.doi.org/10.1002/jpln.201100421

[20] Sikirou, M., Saito, K., Achigan-Dako, E.G., Dramé, K.N., Ahanchédé, A. and Venuprasad, R. (2015) Genetic Improvement of Iron Toxicity Tolerance in Rice-Progress, Challenges and Prospects in West Africa. Plant Production Science, 18, 423-434. http://dx.doi.org/10.1626/pps.18.423

[21] Ouattara, A.S. (1992) Contribution to the Study of Iron-Reducing Bacteria and Sulfate in Paddy Soils of the Kou Valley (Burkina Faso). Ph.D. Dissertation, University of Provence Aix-Marseille I, Marseille.

[22] Wellens, J. and Nitcheu, M.N. (2010) Appropriation and Popularization of Tools of Decision Support in the Co-Management of the Perimeter Irrigated of the Kou Valley (Southwest of Burkina Faso). http://www.ge-eau.org/Documents/SIMIS etude $\% 20 \mathrm{de} \% 20$ cas.pdf

[23] Keita, A., Yacouba, H., Hayde, L.G. and Schultz, B. (2013) A Single-Season Irrigated Rice Soil Presents Higher Iron Toxicity Risk in Tropical Savannah Valley Bottoms. Open Journal of Soil Science, 3, 314-322. http://dx.doi.org/10.4236/ojss.2013.37036

[24] Dobermann, A. and Fairhurst, T. (2000) Rice: Nutrient Disorders \& Nutrient Management. International Rice Research Institute, Los Baños, 191.

[25] Becker, M. and Asch, F. (2005) Iron Toxicity in Rice - Conditions and Management Concepts. Journal of Plant Nutrition and Soil Science, 168, 558-573. http://dx.doi.org/10.1002/jpln.200520504

[26] Engel, K., Asch, F. and Becker, M. (2012) In Vivo Staining of Reduced Iron by 2,2' Bipyridine in Rice Exposed to Iron Toxicity. Journal of Plant Nutrition and Soil Science, 175, 548-552. http://dx.doi.org/10.1002/jpln.201200096

[27] Ponnamperuma, F.N. (1972) The Chemistry of Submerged Soils. Advances in Agronomy, 24, 29-96. http://dx.doi.org/10.1016/S0065-2113(08)60633-1

[28] Sahrawat, K.L. and Diatta, S. (1995) Nutrient Management and Season Affect Soil Iron Toxicity. In: ADRAO, Ed., Annual Report, West Africa Rice Development Association, Bouaké, 62-66.

[29] Ethan, S. and Odunze, S. (2011) Effect of Water Management and Nitrogen Rates on Iron Concentration and Yield in Lowland Rice. Agriculture and Biology Journal of North America, 2, 622-629. http://dx.doi.org/10.5251/abjna.2011.2.4.622.629

[30] Coaxes, J.D., Phillips, E.J.P., Lonergan, D.J., Jenter, H. and Lovley, D.R. (1996) Isolation of Geobacter Species from Diverse Sedimentary Environments. Applied and Environmental Microbiology, 62, 1531-1536.

[31] Holmes, D.E., Finneran, K.T., Neil, R.A.O. and Lovley, D.R. (2002) Enrichment of Members of the Family. Microbiology, 68, 2300-2306.

[32] Wang, X.-J., Yang, J. and Chen, X. (2009) Phylogenetic Diversity of Dissimilatory Ferric Iron Reducers in Paddy Soil of Hunan, South China. Journal of Soils and Sediments, 9, 568-577. http://dx.doi.org/10.1007/s11368-009-0113-x

[33] Yi, W., Wang, B. and Qu, D. (2012) Diversity of Isolates Performing Fe(III) Reduction from Paddy Soil Fed by Different Organic Carbon Sources. African Journal of Biotechnology, 11, 4407-4417.

[34] Luef, B., Fakra, S.C., Csencsits, R., Wrighton, K.C., Williams, K.H., Wilkins, M.J., Downing, K.H., Long, P.E., Comolli, L.R. and Banfield, J.F. (2013) Iron-Reducing Bacteria Accumulate Ferric Oxyhydroxide Nanoparticle Aggregates that May Support Planktonic Growth. The International Society for Microbial Ecology Journal, 7, 338-350. http://dx.doi.org/10.1038/ismej.2012.103 
[35] Hammann, R. and Ottow, J.C.G. (1974) Reductive Dissolution of $\mathrm{Fe}_{2} \mathrm{O}_{3}$ by Saccharolytic Clostridia and Bacillus polymyxa under Anoxic Conditions. Journal of Plant Nutrition and Soil Science, 137, 108-115.

[36] Otoidobiga, C.H., Keita, A., Yacouba, H., Traore, A.S. and Dianou, D. (2015) Dynamics and Activity of Iron-Reducing Bacterial Populations in a West African Rice Paddy Soil under Subsurface Drainage: Case Study of Kamboinse in Burkina Faso. Agricultural Sciences, 6, 860-869. http://dx.doi.org/10.4236/as.2015.68083

[37] Liesack, W., Schnell, S. and Revsbech, N.P. (2000) Microbiology of Flooded Rice Paddies. FEMS Microbiology Reviews, 24, 625-645. http://dx.doi.org/10.1111/j.1574-6976.2000.tb00563.x

[38] Ponnamperuma, F.N., Martinez, E. and Loy, T. (1966) Influence of Redox Potential and Partial Pressure of Carbon Dioxide on $\mathrm{pH}$ Values and the Suspension Effect of Flooded Soils. Soil Science, 101, 421-431. http://dx.doi.org/10.1097/00010694-196606000-00001

[39] Ponnamperuma, F.N., Tianco, E.M. and Loy, T. (1967) Redox Equilibria in Flooded Soils: I. The Iron Hydroxide Systems. Soil Science, 103, 374-383. http://dx.doi.org/10.1097/00010694-196706000-00002

[40] Benckiser, G., Ottow, J.C.G., Watanabe, I. and Santiago, S. (1984) The Mechanism of Excessive Iron-Uptake (Iron Toxicity) of Wetland Rice. Journal of Plant Nutrition, 7, 177-185. http://dx.doi.org/10.1080/01904168409363184

[41] Audebert, A. and Sahrawat, K.L. (2000) Mechanisms for Iron Toxicity Tolerance in Lowland Rice. Journal of Plant Nutrition, 23, 1877-1885. http://dx.doi.org/10.1080/01904160009382150

[42] Singh, B.P., Das, M., Prasad, R.N. and Ram, M. (1992) Characteristics of Fe-Toxic Soils and Affected Plants and Their Correction in Acid Haplaquents of Meghalaya. International Rice Research Newsletter, 17, 18-19.

[43] INERA (2000) Descriptive Folders of Rice Cultivars. Institute of Environment and Agricultural Research, Ouagadougou. http://www.inera.bf/

[44] Audebert, A., Narteh, L.T., Kiepe, P., Millar, D. and Beks, B. (2006) Diagnosis of Risk and Approaches to Iron Toxicity Management in Lowland Rice Farming. In: Audebert, A., Narteh, L.T., Kiepe, P., Millar, D. and Beks, B., Eds., Iron Toxicity in Rice-Based Systems in West Africa, ADRAO, Cotonou, 6-17.

[45] Sokona, M.E.B., Boro, A., Hema, A. and Katiella, B. (2010) Diagnostic Study of the Rice Irrigation Scheme of Tiefora, Province of Comoe, Region of the Cascades. Field Report, 2iE, Ouagadougou.

[46] Jutras, G. (2006) Guide of Interpretation of Soil Analysis. http://blog.ac-versailles.fr/formationcapa/public/MP2/Interpretation_AnalyseSol_.pdf

[47] Vizier, J.F. and Blanch, C. (1969) Selection and Development of a Method for Iron Ferrous Dosage in Waterlogged Soils. Pedology Serial, ORSTOM Books, Montpellier.

[48] Chapman, H.D. and Pratt, P.F. (1961) Methods of Analysis for Soils, Plants and Waters. University of California, California.

[49] Murphy, J. and Riley, J.P. (1962) A Modified Single Solution Method for Determination of Phosphorus in Natural Waters. Analytica Chimica Acta, 27, 31-36. http://dx.doi.org/10.1016/S0003-2670(00)88444-5

[50] Trolldenier, G. (1977) Mineral Nutrition and Reduction Processes in the Rhizosphere of Rice. Plant and Soil, 47, 193202. http://dx.doi.org/10.1007/BF00010379

[51] Bongoua Devisme, A.J. (2009) Iron-Reducing Bacterial Communities Implications and Environmental Settings in the Functioning and Rice Fields Soils Quality (Thaïlande and Ivory Coast). Ph.D. Thesis, Henri Poincare University, Nancy.

[52] Berthelin, J., Jacq, V.A., Prade, K. and Ottow, J.C.G. (1991) Iron Sulphide Accumulation in the Rhizosphere of Wetland Rice (Oryza sativa L.) as the Result of Microbial Activities. Developments in Geochemistry, 6, 453-468. http://dx.doi.org/10.1016/B978-0-444-88900-3.50049-7

[53] Prade, K., Ottow, J.C.G. and Jacq, V.A. (1993) Excessive Iron Uptake (Iron Toxicity) by Wetland Rice (Oryza sativa L.) on an Acid Sulphate Soil in the Casamance/Senegal. International Institute for Land Reclamation and Improvement, Wageningen, the Netherlands. International Livestock Research Institute Publication, 44, 150-162.

[54] Jones, U.S., Katyal, J.C., Mamaril, C.P. and Park, C.S. (1982) Wetland Rice-Nutrient Deficiencies Other than Nitrogen. In: IRRI, Ed., Rice Research Strategies for the Future, International Rice Research Institute, Manila, 327-378.

[55] Panda, B.B., Sharma, S., Mohapatra, P.K. and Das, A. (2012) Application of Excess Nitrogen, Phosphorus, and Potassium Fertilizers Leads to Lowering of Grain Iron Content in High-Yielding Tropical Rice. Communications in Soil Science and Plant Analysis, 43, 2590-2602. http://dx.doi.org/10.1080/00103624.2012.716122

[56] Ito, T., Nielsen, J.L., Okabe, S., Watanabe, Y. and Nielsen, P.H. (2002) Phylogenetic Identification and Substrate Uptake Patterns of Sulfate-Reducing Bacteria Inhabiting an Oxic-Anoxic Sewer Biofilm Determined by Combining Microautoradiography and Fluorescent in Situ Hybridization. Applied and Environmental Microbiology, 68, 356-364. http://dx.doi.org/10.1128/AEM.68.1.356-364.2002

[57] Amann, R.I., Ludwig, W. and Schleifer, K. (1995) Phylogenetic Identification and in Situ Detection of Individual Mi- 
crobial Cells without Cultivation. Microbiological Reviews, 59, 143-169.

[58] Fernández, S.A., Menes, J., Ferrando, L. and Tarlera, S. (2010) Bacterial Community Analysis of the Water Surface Layer from a Rice-Planted and an Unplanted Flooded Field. Brazilian Journal of Microbiology, 41, 411-419. http://dx.doi.org/10.1590/S1517-83822010000200023

[59] Jorgensen, B.B. (1982) Mineralization of Organic-Matter in the Sea Bed: The Role of Sulfate Reduction. Nature, 296, 643-645. http://dx.doi.org/10.1038/296643a0

[60] Wind, T., Stubner, S. and Conrad, R. (1999) Sulfate-Reducing Bacteria in Rice Field Soil and on Rice Roots. Systematic and Applied Microbiology, 22, 269-279. http://dx.doi.org/10.1016/S0723-2020(99)80074-5

[61] Asch, F., Becker, M. and Kpongor, D.S. (2005) A Quick and Efficient Screen for Resistance to Iron Toxicity in Lowland Rice. Journal of Plant Nutrition and Soil Science, 168, 764-773. http://dx.doi.org/10.1002/jpln.200520540

[62] Mahato, P.S., Gunri, K., Chandra, K. and Ghosh, M. (2007) Effects of Varying Levels of Fertilizer and Spacing on Medium Duration Rice (Oryza sativa L.) in Tarai Zones of West Bengal. Karnataka Journal of Agricultural Sciences, 20, 363-365.

[63] Shu, Y.-Y. and Chung, R. (2006) Rice Growth and Nutrient Accumulation as Affected by Different Composts. Communications in Soil Science and Plant Analysis, 37, 1139-1156. http://dx.doi.org/10.1080/00103620600588470

\section{Submit or recommend next manuscript to SCIRP and we will provide best service for you:}

Accepting pre-submission inquiries through Email, Facebook, Linkedin, Twitter, etc A wide selection of journals (inclusive of 9 subjects, more than 200 journals)

Providing a 24-hour high-quality service

User-friendly online submission system

Fair and swift peer-review system

Efficient typesetting and proofreading procedure

Display of the result of downloads and visits, as well as the number of cited articles

Maximum dissemination of your research work

Submit your manuscript at: http://papersubmission.scirp.org/ 